\title{
Leukoencephalopathy after "chasing the dragon" of synthetic cannabinoid (bonsai) abuse: Case report and review of the literature
}

\section{Sentetik kannabinoid (bonzai) kullanım sonrası gelişen lökoensefalopati: Olgu sunumu ve literatürün gözden geçirilmesi}

\author{
Betül ÖZDiLEK ${ }^{1}$, Tuğce TOPTAN² ${ }^{2}$ Gülay KENANGiL², Mustafa ÜLKER², Füsun MAYDA DOMAÇ²
}

ABSTRACT

A 17-year-old male who had abused bonsai, consisting of synthetic cannabinoids for three years, was brought in the hospital by ambulance after vapor inhalation -"chasing the dragon"- of bonsai on the day of symptom onset and presented with signs, and symptoms of acute pyramidal, extrapyramidal, cerebellar system and neurobehavioral changes, which rapidly progressed to akinetic mutism. His cranial magnetic resonance imaging findings were similar to those of toxic leukoencephalopathy. We have emphasized that the use of bonsai is becoming increasingly common in developing countries, mainly among children and young adults, as a result of incredibly low price and easy availability.

Keywords: Bonsai, akinetic mutism, neuroimaging, leukoencephalopathy öz

Üç yıldır sentetik kannabinoid içeren bonzai adlı maddeyi kötüye kullanan 17 yaşında erkek ergen, hastaneye maddeyi buhar ile içine çekme sonrası gelişen akut piramidal, ekstrapiramidal, serebellar sistem ve nörodavranışsal bozuklukla başlayıp hızlıca akinetik mutizme ilerleyen durum nedeniyle ambulans ile başvurdu. Yapılan kraniyal manyetik rezonans görüntülemede toksik lökoensefalopati ile benzer bulgular saptandı. Bonzai kullanımı inanılmaz düşük fiyat ve kolay ulaşılabilirlik nedeniyle gelişmekte olan bizim gibi ülkelerde özellikle çocuklarda ve genç erişkinlerde çok sıklaşmaktadır.

Anahtar kelimeler: Bonzai, akinetik mutizm, nörogörüntüleme, lökoensefalopat

\section{INTRODUCTION}

Substances containing synthetic cannabinoids in general are referred to as "spice" in European countries, "K2" in the United States of America, and "bonsai" in our country. Some synthetic cannabinoids are sprayed into herbal contents and herbal cigarette mixtures and smoked like cannabis by abusers ${ }^{1}$. Although synthetic cannabinoids are usually smoked like cigarettes; a practice named "chasing the dragon" of heroin, namely abuse through vapor inhalation on heated aluminum foil is often seen ${ }^{2,3}$. Their oral or rectal use has been also practiced, although parenteral way of abuse not been used yet ${ }^{2,3}$. Following absorption of synthetic cannabinoids into the lungs by smoking or inhalation, and their diffusion into some organs like brain, their effects are felt immediately ${ }^{2}$. Synthetic cannabinoids have a higher affinity than endogenous cannabinoids for receptors, resulting in an effect stronger when compared that of natural cannabis ${ }^{4}$. Cannabinoid receptors (CB1) are dispersed heterogeneously, mainly in the substantia nigra, globus pallidus, hippocampus, limbic cortex and cerebellum throughout the brain ${ }^{5}$. Synthetic cannabi-

Received: 02.07.2017

Accepted: 30.09.2017

${ }^{1}$ Department of Neurology, Istanbul Medeniyet University School of Medicine, Neurology Clinic, Goztepe Training and Research Hospital, Istanbul, Turkey

${ }^{2}$ Neurology Clinic, Erenkoy Training and Research Hospital for Neurologic and Psychiatric Disorders, Istanbul, Turkey

Yazışma adresi: Betül Özdilek, Department of Neurology, Istanbul Medeniyet University School of Medicine, Neurology Clinic, Goztepe Training and Research Hospital, Istanbul, Turkey

e-mail: ozdilekbetul@gmail.com 
noids have some acute and chronic neurologic and psychoactive effects such as mood elevation, anxiety and panic reactions, analgesia, decreased motor functions, deterioration in memory and time perception, and impaired visual and auditory perception. Acute symptoms are just like those of "chasing the dragon" of heroin ${ }^{3,6,7}$. Several literature reports that illegal drugs-especially heroin- cause toxic leukoencephalopathy characterized by degenerated white matter of central nervous system and vacuolated oligodendroglia ${ }^{8-10}$. However, no report indicating leukoencephalopathy induced by synthetic cannabinoids has been presented before, except only a brief case poster presentation ${ }^{11}$.

We herein present a 17-year-old male patient with pyramidal, extrapyramidal, cerebellar system signs and neurobehavioral changes clinically manifesting as a prominent akinetic mutism and leukoencephalopathy on cranial magnetic resonance imaging (MRI). We have emphasized that the use of bonsai is becoming increasingly more common in developing countries, mainly among children and young adults, and may lead to permanent neurological sequelae.

\section{CASE REPORT}

A 17-year-old male patient transported to the emergency room by ambulance with complaints of confusion, weakness in the left arm, slow motor movements and speech, and imbalance. He had been using bonsai for three years at various intervals and had ingested it by vapor inhalation -"chasing the dragon"- on the day of symptom onset. His medical history was unremarkable other than a similar attack two months previously that lasted one week without sequelae. He did not use alcohol or cigarettes.

The initial neurological examination revealed that the patient was confused with restricted cooperation. He had no signs of meningeal irritation or neck stiffness. He had dysarthria and hypophonic speech. Although his reaction time was elongated, he occasionally responded to single commands. He followed the doctor with his eyes. The patient was diagnosed with akinetic mutism. Diameters of his pupils were 4 $\mathrm{mm}$ and they were reactive to light; however, pursuit and saccadic eye movements were very slow. He had inappropriate crying episodes. The muscular power of his left arm was $3 / 5$, and his deep tendon reflexes were hyperactive globally. He had a masked face and exhibited truncal, limb, and gait ataxia. He also had a bilateral grasping reflex.

No abnormalities were found in his laboratory analysis including complete blood count, biochemical microbiological or serologic tests. His urine level of synthetic cannabinoids was $<4 \mathrm{ng} / \mathrm{ml}$ (normal, $<20$ $\mathrm{ng} / \mathrm{ml}$ ), and a sample check was $97 \%$ (normal range, 85\%-105\%). Other drug screening test results performed with urine and serum samples for heroin and opiates were unremarkable. Results of biochemical, microscopic, and cultural analysis of the cerebrospinal fluid were within normal limits. Electroencephalography showed generalized slow-wave activity in the theta range.

Prevalent bilateral, diffuse foci of periventricular white matter hyperintensity and bilateral cerebellar hyperintensity on T2-weighted and FLAIR images and hypointensity on T1-weighted images were observed on MRI. All cerebellar lesions and

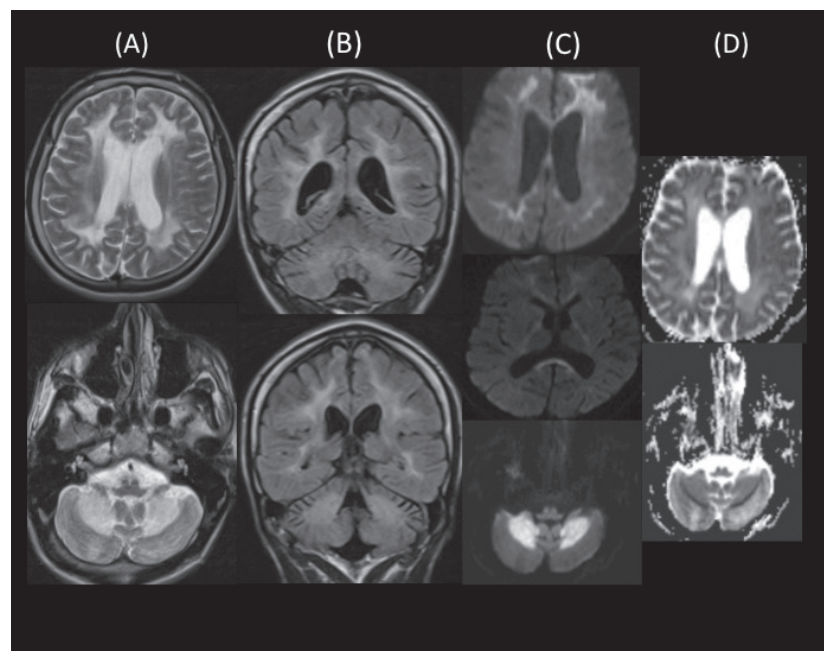

Figure 1 (A-D). Bilateral, diffuse periventricular white matter hyperintensity and bilateral cerebellar hyperintensity on (A) T2-weighted MRI and (B) FLAIR images. Hyperintensity was seen on (C) diffusion-weighted MRI, and (D) a restricted apparent diffusion coefficient was seen on MRI. 
some periventricular lesions were hyperintense on diffusion-weighted MRI without a restricted apparent diffusion coefficient (Figure 1A-D). According to clinic and radiologic findings, the patient was diagnosed with acute and chronic toxic leukoencephalopathy due to drug abuse.

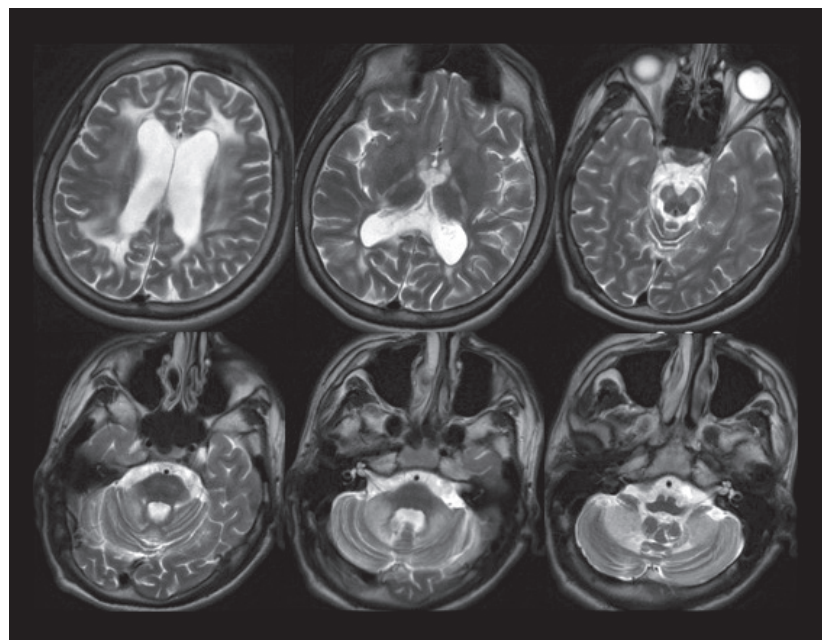

Figure 2. Three months later, the same hyperintense lesions were seen on T2-weighted MRI images.

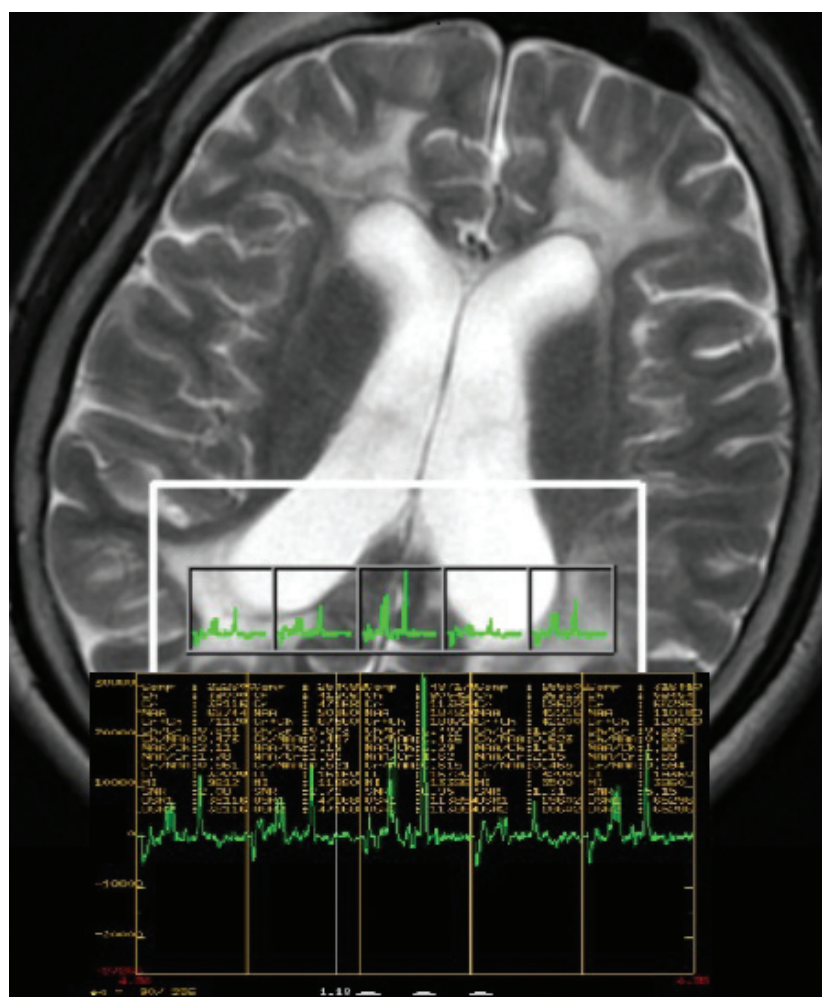

Figure 3. Although there was no prominent choline peak, the decrease in $\mathrm{N}$-acetylaspartate supported demyelination on MR spectroscopy.
Intravenous pulse methylprednisolone in a dose of $1000 \mathrm{mg}$ per day was administered to the patient for 10 days. General supportive treatment and physiotherapy were also performed. On follow-up examinations, although his clinical status partially recovered after 3 months, the white matter lesions on MRI were persistent with global atrophy and secondary hydrocephalus (Figure 2). Additionally, the lesions were congruent with demyelination (although there was no prominent choline peak, the decrease in $\mathrm{N}$-acetylaspartate supported demyelination) on $\mathrm{MR}$ spectroscopy at 3 months (Fig. 3).

\section{DISCUSSION}

Synthetic cannabinoids are usually smoked like cigarettes and a practice named "chasing the dragon", that is vapor inhalation of heroin as heated on a piece of aluminum foil ${ }^{2}$. In this way of abuse, the person places heroin on an aluminum foil, makes it heated with flame below and, then inhales resulting vapor by a straw or a tube-like structure ${ }^{3}$. The presented patient here abused bonsai using a plastic bottle. This practice, first recognized in Hong Kong in the 1950 's, is being much more popular since it prevents the risks of parenteral way of abuse.

After the first synthetic cannabinoid produced experimentally by John W. Huffman (JWH) in 1990s, number of the species increased annually ${ }^{12}$. European Monitoring Center for Drugs and Drug Addiction reported 169 kinds of synthetic cannabinoids in $2016^{13}$. Although different classifications are made, synthetic cannabinoids are divided into eight chemical groups within themselves. These groups include adamantoil indoles (e.g., AKB-48), aminoalkyl indoles, benzoyl indoles (e.g., AM-694), cyclohexylphenoles, dibenzopyrans, naphthyl methyl indoles (e.g., JWH-018), naphthyl methyl indenes (e.g., JWH-176), naphthoyl pyrroles (e.g., JWH-307), phenylacetyline indoles (e.g., JWH-250) and indazole caboxamide products ${ }^{14,15}$. All of these synthetic cannabinoids have similar structures chemically and seem to be able to bind strongly to CB1 receptors in the central nervous system. Agonists of CB1 receptors cause 
a depolarization-induced suppression of inhibition, resulting in reduction of GABA release, associated with deterioration of neurobehavioral functions ${ }^{15}$. Correlating clinical and MRI findings in our case have shown probably dose dependent toxic leukoencephalopathy. Synthetic cannabinoids are even more potent than $\Delta 9$-tetrahydrocannabinol (natural cannabis), which are shown to cause toxic leukoencephalopathy ${ }^{15}$.

Toxic leukoencephalopathy progressed following the practice named "chasing the dragon", first presented in Netherlands by Wolters and colleagues in 1982, which has been shown to be present in many heroin abusers during the past decades. The patients with toxic leukoencephalopathy may have various symptoms, but generally stupor, coma, and they unfortunately lose their lives after a latent period of hours, days or even months following the exposure. Its clinical presentation is described in three distinct stages. At first, the abuser may suffer pseudobulbar palsy, motor restlessness, and cerebellar ataxia. In the second stage, worsening cerebellar symptoms, hyperactive deep tendon reflexes, myoclonic jerks, and spastic hemiplegia or quadriplegia may be seen, whereas the complaints of stretching spasms, profuse diaphoresis, central fever, hypotonic areflexic paresis and akinetic mutism in the terminal stage and eventually death may be also observed ${ }^{3}$. In our case, the patient has manifested devastating outcome of all these, although not each patient progresses through all of the stages and some may only show clinical symptoms of the first stage especially if the disorder is mild.

Documented exposure to a toxin, neurobehavioral disorders and neuroradiologic abnormalities are three criteria for the diagnosis of toxic leukoencephalopathy. In the case we presented, the patient showed cerebellar, pyramidal, extrapyramidal and neurobehavioral changes, which rapidly progressed to akinetic mutism. He had MRI findings similar to toxic leukoencephalopathy with both vasogenic and cytotoxic edema. This is the first report of MRI showing cerebral and cerebellar white matter involvement, demye- lination, and vasogenic edema secondary to bonsai abuse. MRI findings are nonspecific for synthetic cannabinoids. Literature mostly reports cerebrovascular infarcts ${ }^{16}$. Toxic leukoencephalopathy was reported in heroin abuse, but not reported in abuse of synthetic cannabinoids ${ }^{9,17}$. MRI findings of toxic leukoencephalopathy reveal increased signal intensity on T2-weighted and FLAIR images in both cerebral and cerebellar white matter, just similar to the case reported herein. During the acute stages, restricted diffusion is also observed on diffusion-weighted MRI secondary to cytotoxic edema ${ }^{10}$.

The toxicology parameters were negative for heroin, other drugs and also for synthetic cannabinoids. It is not easy to detect synthetic cannabinoids as they are not recorded in any volume spectrometer system and they have no reference standards. To detect substance abuse, the serum, blood, saliva, urine and hair samples are used ${ }^{4}$. The analysis of body fluids was mainly based on the detection of main substance in the past, but substance abuse cannot be proved after their metabolization because there are not enough data about their metabolites ${ }^{7}$. Although results of toxicological analysis was unremarkable, we were so sure that all presented symptoms and radiologic findings resulted from bonsai abuse. Our patient talked about synthetic cannabinoids abuse on the day he admitted to the hospital and also for a long time before. Therefore, he met criteria for a toxic leukoencephalopathy.

Unfortunately, any effective treatment which eliminates the effects of exposure to cannabinoids and provides supportive care have been established for toxic leukoencephalopathy. Our aim is to inform clinicians about the harm posed by these synthetic cannabinoids because their use is becoming increasingly more common in developing countries due to extremely low price and easy availability.

\section{Disclosure Statements}

The authors state that they have no conflict of interests. 


\section{REFERENCES}

1. Vardakou I, Pistos C, Spiliopoulou Ch. Spice drugs as a new trend: Mode of action, identification and legislation. Toxicol Lett. 2010;197:157-62. https://doi.org/10.1016/j.toxlet.2010.06.002

2. Vandrey R, Dunn KE, Fry JA, Girling ER. A survey study to characterize use of Spice products (synthetic cannabinoids). Drug Alcohol Depend. 2012;120:238-41. https://doi.org/10.1016/j.drugalcdep.2011.07.011

3. Wolters EC, van Wijngaarden GK, Stam FC, et al. Leucoencephalopathy after inhaling "heroin" pyrolysate. Lancet. 1982;2(8310):1233-7. https://doi.org/10.1016/S0140-6736(82)90101-5

4. Hudson S, Ramsey J, King L, et al. Use of high resolution accurate mass spectrometry to detect reported and previously unreported cannabinomimetics in "herbal high" products. J Anal Toxicol. 2010;34:252-60. https://doi.org/10.1093/jat/34.5.252

5. Quickfall J, Crockford D. Brain neuroimaging in cannabis use: a review. J Neuropsychiatry Clin Neurosci. 2006;18:318-32. https://doi.org/10.1176/jnp.2006.18.3.318

6. Schneir AB, Cullen J, Ly BT. "Spice" girls: Synthetic cannabinoid intoxication. J Emerg Med. 2011;40:296-9. https://doi.org/10.1016/j.jemermed.2010.10.014

7. Wintermeyer A, Möller I, Thevis M, et al. In vitro phase I metabolism of the synthetic cannabimimetic JWH-018. Anal Bioanal Chem. 2010;398:2141-53. https://doi.org/10.1007/s00216-010-4171-0

8. Tamrazi B, Almast J. Your brain on drugs: imaging of drugrelated changes in the central nervous system. Radiographics. 2012;32(3):701-19. https://doi.org/10.1148/rg.323115115
9. Bach AG, Jordan B, Wegener NA, et al. Heroin spongiform leukoencephalopathy (HSLE). Clin Neuroradiol. 2012;22(4):345-9. https://doi.org/10.1007/s00062-012-0173-y

10. Geibprasert S, Gallucci M, Krings T. Addictive illegal drugs: structural neuroimaging. AJNR Am J Neuroradiol. 2010;31(5):803-8. https://doi.org/10.3174/ajnr.A1811

11. Topcu M, Serdaroglu E, Okar SV, et al. Toxic leukoencephalopathy in synthetic cannabinoid abuse. Eur J Paediatr Neurol. 2015;19(Supp1):S143. https://doi.org/10.1016/S1090-3798(15)30490-6

12. Huffman JW, Dai D. Design, synthesis and pharmacology of cannabimimetic indoles. Bioorg Med Chem Lett. 1994;4:563-6.

https://doi.org/10.1016/S0960-894X(01)80155-4

13. Annual report on the state of the drugs problem in Europe, EMCDDA, Lisbon, 2016.

14. Castaneto MS, Gorelick DA, Desrosiers NA, et al. Synthetic cannabinoids: Epidemiology, pharmacodynamics, and clinical implications. Drug Alcohol Depend. 2014;144:12-41. https://doi.org/10.1016/j.drugalcdep.2014.08.005

15. Gurney SM, Scott KS, Kacinko SL, et al. Pharmacology, Toxicology, and Adverse Effects of Synthetic Cannabinoid Drugs. Forensic Sci Rev. 2014;26(1):53-78.

16. Rojas R, Riascos R, Vargas D, et al. Neuroimaging in drug and substance abuse part I: cocaine, cannabis, and ecstasy. Top Magn Reson Imaging. 2005;16(3):231-8. https://doi.org/10.1097/01.rmr.0000192156.46492.24

17. Keogh CF, Andrews GT, Spacey SD, et al. Neuroimaging features of heroin inhalation toxicity: "chasing the dragon." AJR Am J Roentgenol. 2003;180(3):847-50. https://doi.org/10.2214/ajr.180.3.1800847 